\title{
Analisis Prediksi Kelulusan Mahasiswa Menggunakan Decission Tree Berbasis Particle Swarm Optimization
}

\author{
Hendra $^{[1] *}$, Mochammad Abdul Azis ${ }^{[2]}$, Suhardjono $^{[3]}$ \\ Program Studi Ilmu Komputer STMIK Nusa Mandiri ${ }^{[1]}$, \\ Program Studi Sistem Informasi Universitas Bina Sarana Informatika ${ }^{[2][3]}$ \\ 14002267@nusamandiri.ac.id ${ }^{[1]}$, mochammad.mmz@bsi.ac.id ${ }^{[2]}$,Suhardjono@bsi.ac.id ${ }^{[3]}$
}

\begin{abstract}
Good accreditation results are the goal of the college. With good accreditation, prospective students can glance at and enter the tertiary institution. To achieve this, there are several aspects that affect good accreditation results, one of which is graduate students who play an important role in determining accreditation. Timely graduate students can benefit the college or a student. Graduates can be predicted before the final semester using a method one of which is the decision tree. Decision tree is a method that is simple and easy to understand by producing rules in the form of a decision tree, but using a decision tree model alone is not enough to produce optimal results. So we need a method for optimization that is particle swarm optimization with advantages can improve accuracy by eliminating unused features. From the results of research with primary data of 2000-2003 graduate students in Amik PPMI Tangerang explained that the particle swarm optimization method can increase accuracy by $87.56 \%$ and increase by $01.01 \%$ from the decision tree method with a value of $86.55 \%$. From the particle swarm optimization method can also find out which unused attributes have no weight, so that way can improve accuracy. From the results of the increase, it can be used by the Amik University of Tangerang to prevent students from graduating on time.
\end{abstract}

Keywords - Decision Tree, Student Graduation, Particle Swarm Optimization.

Abstrak-Hasil akreditasi yang baik merupakan tujuan dari perguruan tinggi. Dengan adanya akreditasi yang baik membuat para calon mahasiswa dapat melirik dan masuk perguruan tinggi tersebut. Untuk mencapai tersebut ada beberapa aspek yang mempengaruhi hasil akreditasi yang baik, salah satunya mahasiswa lulusan yang merupakan peran penting dalam menentukan akreditasi. Mahasiswa lulusan yang tepat waktu dapat menguntungkan bagi perguruan tinggi tersebut ataupun bagi seorang mahasiswa. Mahasiswa lulusan dapat diprediksi sebelum semester akhir dengan menggunakan sebuah metode salah satunya yaitu decision tree. Decision tree merupakan metode yang sederhana dan mudah dipahami dengan menghasilkan rule-rule berupa pohon keputusan, akan tetapi menggunakan model decision tree saja tidak cukup untuk menghasilkan hasil yang optimal. Maka dibutuhkan metode untuk pengoptimalan yaitu particle swarm optimization dengan kelebihan dapat meningkatkan akurasi dengan cara menghilangkan fitur yang tidak terpakai. Dari hasil penelitian dengan data primer mahasiswa lulusan tahun 2000-2003 pada amik ppmi tangerang menerangkan bahwa metode particle swarm optimization dapat meningkatkan akurasi sebesar $87.56 \%$ dan meningkatkan sebesar $01.01 \%$ dari metode decision tree dengan nilai $86.55 \%$. Dari metode particle swarm optimization juga dapat mengetahui mana atribut yang tidak terpakai yang tidak memiliki bobot, sehingga cara tersebut dapat meningkatkan akurasi. Dari hasil kenaikan tersebut dapat dipakai oleh perguruan tinggi amik tangerang untuk menghindari mahasiswa lulus tidak tepat waktu.

Kata Kunci-Decision Tree, Kelulusan Mahasiswa, Particle Swarm Optimization.

\section{PENDAHULUAN}

Perguruan tinggi untuk menentukan hasil akreditasi perguruan tinggi atau program studinya dapat ditentukan dari beberapa aspek salah satunya mahasiswa yang lulus. Kelulusan mahasiswa sangat berpengaruh dalam menjalani proses akademik sebuah perguruan tinggi. Terlebih kelulusan mahasiswa sangat dinantikan bagi mahasiswanya sendiri maupun orang tua atau keluarganya. Mahasiswa dalam kelulusan sangat berharap lulus dengan tepat waktu, dikarenakan dengan lulus tepat waktu dapat membantu mahasiswa dalam mencari kerjaan dengan cepat dan dapat melanjutkan ke jenjang berikutnya. Kelulusan dengan terlambat dapat mengakibatkan hasil akreditasi atau kualitas perguruan tinggi menurun serta memerlukan dosen yang lebih untuk memenuhi rasio dosen. Kelulusan dapat diprediksi sebelum mahasiswa tersebut mencapai semester akhir maka diperlukan evaluasi dalam proses belajar mengajar, sehingga dapat diperbaiki prestasi mahasiswa. Untuk memperbaiki prestasi mahasiswa sebuah perguruan tinggi tentu saja mempunyai data mahasiswa di server yang mereka simpan sendiri dan untuk menganalisa dan mengambil suatu informasi dari data tersebut tidak mudah, mengingat data yang sangat besar dan tidak memiliki kecerdasan dalam keahlian data yang tersimpan tersebut.

Ada beberapa data yang tersimpan dalam perguruan tinggi tapi tidak mempengaruhi dengan kelulusan mahasiswa. Kelulusan mahasiswa dipengaruhi dari data yang ada seperti jurusan SLTA, asal SLTA, jenis kelamin dan tentu saja IPK [1]. Penelitian tentang kelulusan dengan menganalisis faktor IPK yang diduga dapat mempengaruhi kelulusan mahasiswa ternyata tidak signifikan dengan kelulusan mahasiswa tersebut [2]. Peneliti lain juga telah melakukan dengan ketiga metode 
NN, NB dan DT dengan hasil bahwa metode NN lebih tinggi akurasi yang didapat dibandingkan dengan metode yang lain [3], Ada juga yang membandingkan metode dari ketiga tersebut dengan menambahkan metode regresi dengan data yang berbeda akan tetapi dari hasil tersebut bahwa metode NB mendapatkan nilai akurasi tertinggi [4]. Dari atribut yang disebutkan ada beberapa metode untuk memprediksi suatu data tersebut contohnya Decision Tree (DT), Neural Network (NN), Support Vector Machine (SVM) dan Nä̈ve Bayes (NB). Dari metode tersebut sudah pernah dilakukan untuk kelulusan mahasiswa dengan ketiga metode kecuali metode naïve bayes, dari hasil penelitian yang telah dilakukan akurasi metode support vector machine mendapatkan nilai akurasi tertinggi sebesar $85.18 \%$ dan menempati peringkat pertama dan ditempat kedua dengan akurasi $84.96 \%$ ditempati metode decision tree dan yang ditempat terakhir dengan akurasi $84.68 \%$ yaitu metode neural network [1].

Dari hasil penelitian prediksi kelulusan di kembangkan oleh peneliti lain dengan support vector machine berbasis particle swarm optimization, dimana dari permasalahan yang ada terhadap support vector machine tentang kelemahan optimasi telah ditutupi oleh metode particle swarm optimization, dan dari hasil yang didapat oleh metode PSO sebesar $86.43 \%$ naik menjadi $00.62 \%$ dari metode SVM sebelumnya [5] dan dari hasil penelitian menunjukan adanya peningkatan akurasi terhadap mahasiswa lulusan tersebut, dengan hasil akurasi sebesar $86.43 \%$ dari hasil sebelumnya menggunakan support vector machine sebesar $85.18 \%$ dan mengalami kenaikan sebesar $01.29 \%$. PSO juga dapat meningkatkan akurasi dari metode NN sebesar 00.02\% [6]. Decision tree menghasilkan akurasi terbaik sebesar 84.4\% [7]. Namun penelitian ini tidak menggunakan support vector machine melainkan menggunakan decision tree dimana pada penelitian terdahulu decision tree mendirikan peringkat kedua setelah support vector machine.

Decision tree merupakan metode yang sering dipakai dan populer dari metode lainya dengan peringkat yang kesepuluh [8]. Decission tree mampu menghasilkan pohon keputusan dengan aturan atau rule-rule untuk membuat klasifikasi baru dari nilai atribut menjadi class dengan cara penklasifaksiannya [9]. Decision tree mampu menghasilkan keputusan yang sederhana dari hasil keputusan yang rumit dengan cara mengubahnya menjadi sederhana [10]. Decission tree sangat mudah dimengerti dalam mengolah data yang kecil [11]. Decision tree merupakan metode yang tanpa mengurangi hasil dari kualitas yang didapat dengan menggunakan kriteria setiap node [12].

Dari kelebihan algoritma decision tree diperlukan metode untuk mengoptimasi algoritma tersebut, diantara metode optimasi yang ada penelitian ini menggunakan metode optimasi particle swarm optimization (PSO). Particle swarm optimization merupakan konsep yang sederhana dengan implementasi sangat mudah, dan konvergensi cepat [13]. Terutama proses dalam pemilihan fitur yang secara optimal dapat dilakukan dengan menghilangkan fitur-fitur yang tidak relevan [14]. Dari dilakukan penghilangan fitur yang berlebih akan mengakibatkan akurasi meningkat [15].

\section{BAHAN DAN METODE}

Model decision tree dengan sistem pengambilan keputusan dan menghasilkan sebuah pohon keputusan yang terdiri dari simpul internal, tepi dan simpul daun dengan simpul internal yang merupakan keputusan dengan mewakili setiap set pada atribut dan masing label diberikan dengan masing-masing edge [16]. Model decision tree dengan alur proses untuk membentuk pohon keputusan dalam data mining sebagai berikut: 1). Membuat simpul akar dengan memilih atribut 2). Untuk tiap-tiap nilai akan dibuat cabang. 3). Bagi kasus dalam tiap-tiap cabang. 4). Ulangi proses pembagian untuk tiap-tiap cabang sampai tiap-tiap kasus pada cabang mendapatkan kelas yang sama [7].

Model particle swarm optimization adalah teknik optimisasi global dengan melalui simulasi perilaku social kawanan burung yang sering berkelompok, dengan ide dasarnya adalah pertama menginisialisasi seperangkat partikel acak dan kemudian menemukan solusi optimal dengan menggunakan iterasi [17].

Penelitian ini menggunakan decision tree dengan particle swarm optimization dimana data yang diambil pada tahun 2000-2003 dari satu perguruan tinggi swasta amik tangerang dengan parameter sebanyak 796. Dari data tersebut dilakukan diuji coba menggunakan algoritma DT dan DT berbasis PSO. Sample data kelulusan mahasiswa dari perguruan tinggi swasta dapat dilihat ditabel 1.

Tabel 1. Sample Data Kelulusan Mahasiswa

\begin{tabular}{|c|c|c|c|c|c|c|c|c|c|}
\hline JK & Jurusan SLTA & Asal SLTA & IPK1 & IPK2 & IPK3 & IPK4 & IPK 5 & IPK 6 & HASIL \\
\hline $\mathrm{L}$ & IPA & SMA N 1 Lais & 2,55 & 2,61 & 2,64 & 2,74 & 2,97 & 3 & YA \\
\hline $\mathrm{L}$ & Teknik Komputer Jaringan & SMK TI YPML & 3,23 & 3,15 & 3,07 & 3,17 & 3,25 & 3,17 & YA \\
\hline $\mathrm{P}$ & Administrasi Perkantoran & SMK Nusantara 1 & 2,73 & 2,73 & 2,62 & 2,64 & 2,89 & 3 & YA \\
\hline $\mathrm{L}$ & IPA & SMA Yuppentek 1 & 2,73 & 3,1 & 2,97 & 3,16 & 3,3 & 3,33 & YA \\
\hline $\mathrm{L}$ & IPS & Hidayatul Ikhwan & 2,18 & 2,44 & 2,11 & 2,36 & 2,66 & 2,57 & TIDAK \\
\hline $\mathrm{P}$ & TKJ & SMK Pustek & 2,32 & 2,39 & 2,43 & 2,74 & 2,67 & 2,95 & TIDAK \\
\hline $\mathrm{P}$ & Penjualan & SMK Negeri 1 & 3,64 & 3,56 & 3,59 & 3,53 & 3,53 & 3,51 & YA \\
\hline $\mathrm{L}$ & Otomotif & SMK & 2,64 & 2,22 & 2,3 & 2,11 & 2,49 & 2,74 & YA \\
\hline $\mathrm{L}$ & Otomotif & SMK Negeri 2 & 2,5 & 2,71 & 2,1 & 2,57 & 2,6 & 2,58 & TIDAK \\
\hline $\mathrm{P}$ & IPA & SMA Negeri 1 Jiwan & 2,91 & 3,07 & 2,35 & 2,84 & 3,3 & 2,95 & TIDAK \\
\hline
\end{tabular}


Data pada tabel 1 telah dilakukan penghilangan data yang tidak valid, setelah itu dilakukan normalisasi data dan mentransformasi data dengan decision tree dan particle swarm optimization. Dari data tersebut diuji coba dengan model yang diusulkan yang dapat dilihat pada gambar 1 .

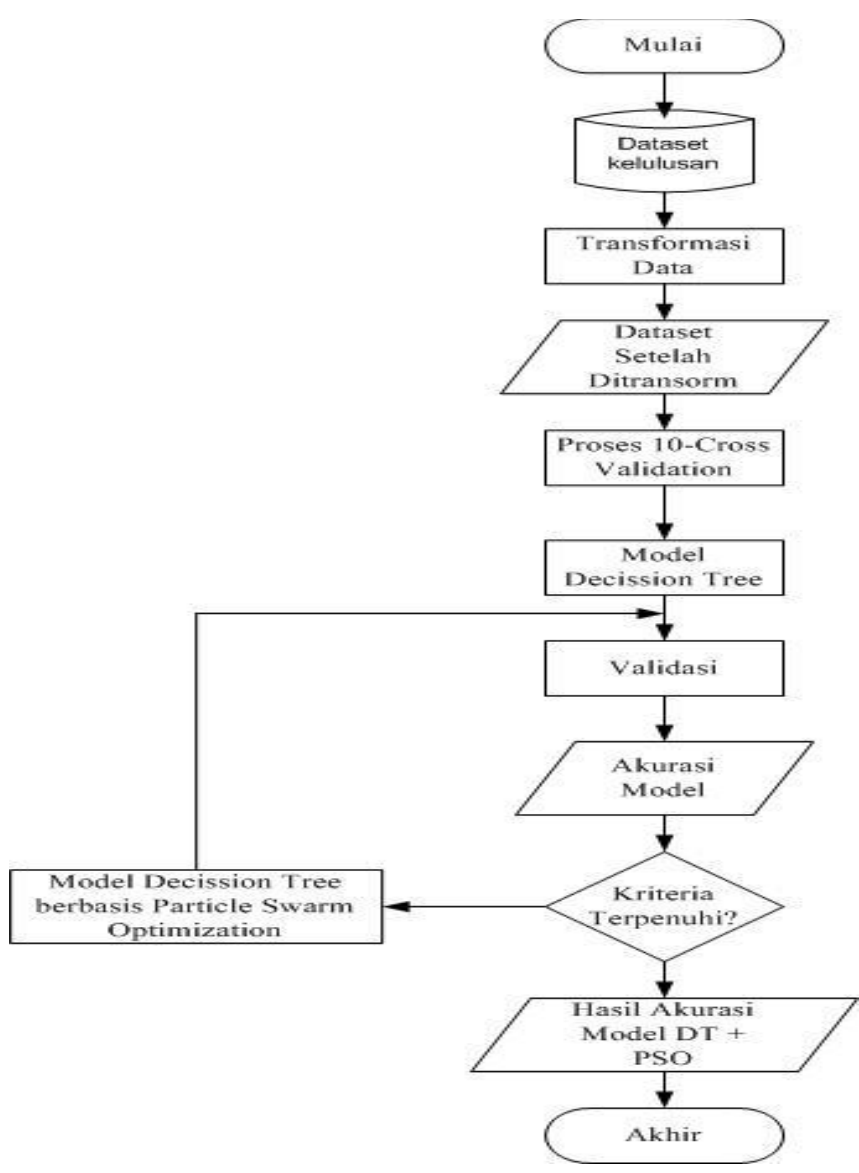

Gambar 1. Model Penelitian yang diusulkan

Setelah data set di transform dan dari hasil pembersihan data, data yang sudah bersih maka dilakukan uji validasi dengan menggunakan 10-cross validation dan model decision tree, setelah itu di validasi dan menghasilkan akurasi dari model decision tree. Jika kriteria akurasi tidak terpenuhi maka dilakukan model dengan particle swarm optimization untuk memperbaiki fitur yang berlebih dan tidak relevan. Jika PSO diterapkan maka divalidasi kembali sehingga mendapatkan akurasi model yang memenuhi kriteria.

\section{HASIL DAN PEMBAHASAN}

Penelitian ini dengan melakukan pengolahan data melalui software rapid miner 9.3 Data yang disudah melalui tahap model penelitian menghasilkan confusion matrix dari metode decision tree yang tertera pada table 2 .

Tabel 2. Confusion Matrix DT

\begin{tabular}{|c|c|c|}
\hline & Ya & Tidak \\
\hline Prediksi Lulus & 582 & 55 \\
\hline $\begin{array}{c}\text { Prediksi Tidak } \\
\text { Lulus }\end{array}$ & 52 & 107 \\
\hline
\end{tabular}

Dari table 2 confussion matrix yang dihasilkan True Negatif (TN) sejumlah 582, False Negatif (FN) sejumlah 52, True Positif (TP) sejumlah 107 dan False Positif (FP) sejumlah 55. Dari data tersebut menerangkan bahwa mahasiswa yang diprediksi lulus tepat sejumlah waktu sejumlah 582 mahasiswa dan prediksi tersebut benar dan sesuai dengan penelitian, sedangkan dengan jumlah mahasiswa yang diprediksi lulus senilai 55 ternyata setelah dilakukan ujicoba dengan metode decision tree mahasiswa tersebut tidak lulus. Untuk mahasiswa yang diprediksi tidak lulus sejumlah 107 dan hasil uji coba model decision tree benar bahwa mahasiswa tersebut tidak lulus, sedangkan dengan jumlah mahasiswa yang diprediksi tidak lulus sejumlah 52 ternyata hasil membuktikan mahasiswa tersebut lulus tepat waktu. Dari tabel tersebut dapat dihitung rumus akurasi dibawah ini.

$$
\begin{gathered}
\text { Akurasi }=\frac{(\mathrm{TN}+\mathrm{TP})}{(\mathrm{TN}+\mathrm{FN}+\mathrm{TP}+\mathrm{FP})} \\
\text { Akurasi }=\frac{(582+107)}{(582+52+107+55)}=0,865578
\end{gathered}
$$

Dengan rumus akurasi decision tree tersebut dapat dihasilkan akurasi dengan model decisission tree sebesar 0.865578 atau diubah dengan persen senilai 60.26\%. Dari hasil prediksi kelulusan mahasiswa dapat dilihat dengan diagram batang di bawah ini.

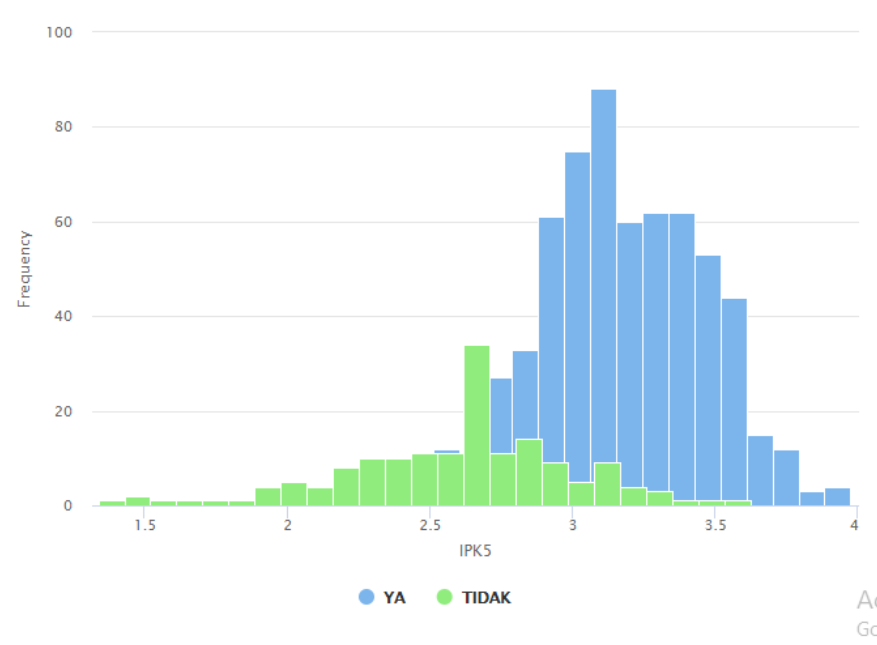

Gambar 2. Digram Batang Model Decision Tree

Dari diagram batang tersebut dapat juga dilihat kurva dengan model decision tree, kurva tersebut merupakan area under curve (AUC) yang dapat dilihat dari gambar 3. 


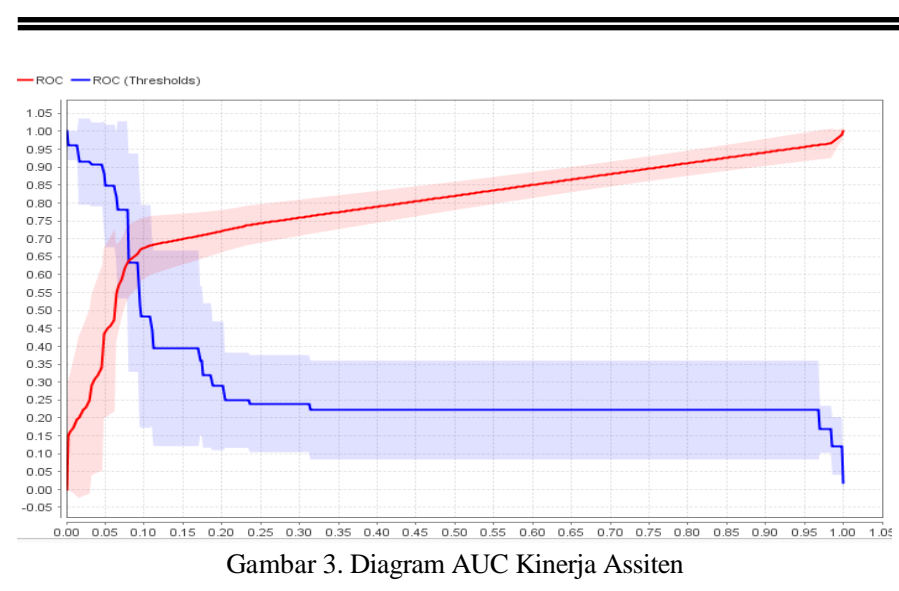

Dari hasil uji coba dengan model decision tree maka didapatkan rule algoritma kelulusan mahasiswa seperti gambar berikut.

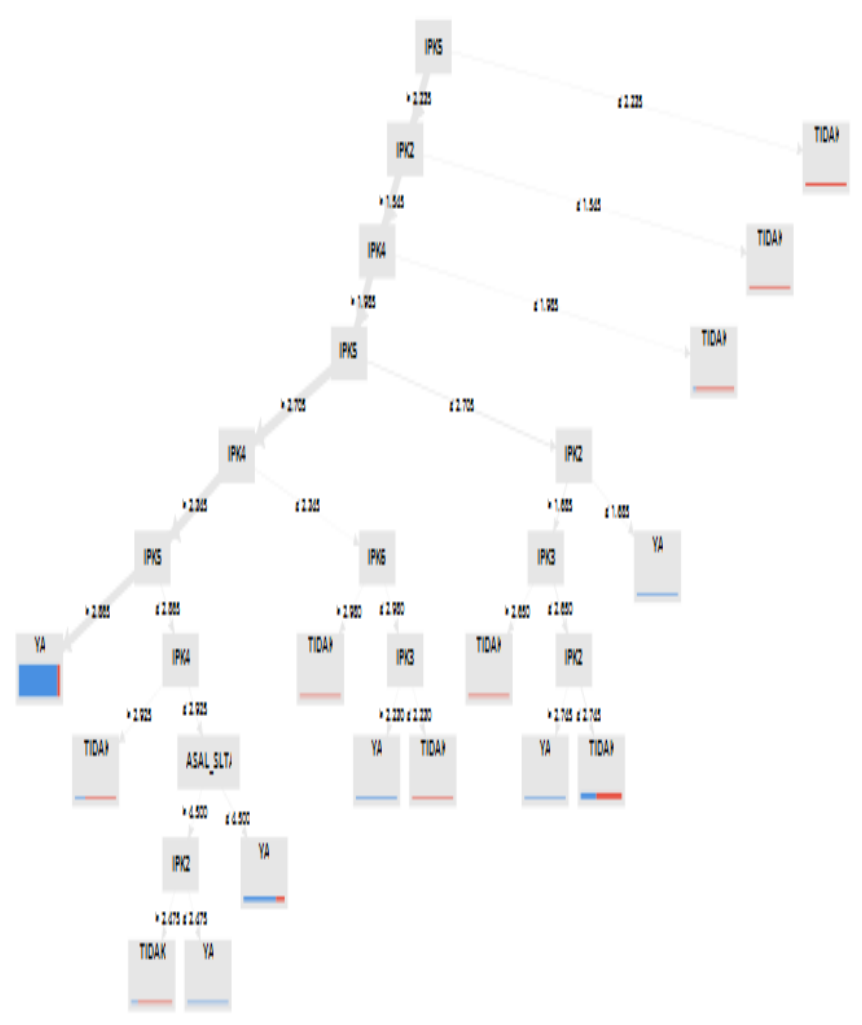

Gambar 4. Rule Algoritma Decision Tree

\begin{tabular}{|c|c|}
\hline Atribut & Bobot \\
\hline Jurusan SLTA & 0.996 \\
\hline Asal SLTA & 1 \\
\hline IPK1 & 0 \\
\hline IPK2 & 0.679 \\
\hline IPK3 & 0 \\
\hline IPK4 & 0.735 \\
\hline IPK5 & 1 \\
\hline IPK6 & 0.230 \\
\hline
\end{tabular}

Setelah di uji coba dengan menggunakan decision tree maka di optimasikan dengan particle swarm optimization. Setelah dilakukan uji coba menggunakan optimasi PSO maka didapatkan bobot atribut yang dapat dilihat pada tabel 3 .

Dari hasil bobot tersebut, terdapat bobot yang tidak mempengaruhi secara signifikan terhadap kelulusan mahasiswa diantarnya atribut IPK1 (ipk semester 1) dan IPK3 (ipk semester 3). Untuk atribut yang lain seperti Jurusan dan Asal SLTA, IPK2, IPK4, IPK5, IPK6 merupakan atribut yang mempengaruhi secara signifikan. Setelah mendapatkan bobot atribut, terdapat juga confussion matrix.

Tabel 4. Confusion Matrix DT+PSO

\begin{tabular}{|c|c|c|}
\hline & Ya & Tidak \\
\hline Prediksi Lulus & 589 & 54 \\
\hline $\begin{array}{c}\text { Prediksi Tidak } \\
\text { Lulus }\end{array}$ & 45 & 108 \\
\hline
\end{tabular}

Dari table 4 confussion matrix yang dihasilkan True Negatif (TN) sejumlah 589, False Negatif (FN) sejumlah 45, True Positif (TP) sejumlah 108 dan False Positif (FP) sejumlah 54. Dari data tersebut menerangkan bahwa mahasiswa yang diprediksi lulus tepat waktu sejumlah 589 mahasiswa dan prediksi tersebut benar dan sesuai dengan penelitian, sedangkan dengan jumlah mahasiswa yang diprediksi lulus senilai 54 ternyata setelah dilakukan ujicoba dengan metode decision tree mahasiswa tersebut tidak lulus. Untuk mahasiswa yang diprediksi tidak lulus sejumlah 108 dan hasil uji coba model decision tree benar bahwa mahasiswa tersebut tidak lulus, sedangkan dengan jumlah mahasiswa yang diprediksi tidak lulus sejumlah 45 ternyata hasil membuktikan mahasiswa tersebut lulus tepat waktu. Dari tabel tersebut dapat dihitung rumus akurasi dibawah ini.

$$
\begin{gathered}
\text { Akurasi }=\frac{(\mathrm{TN}+\mathrm{TP})}{(\mathrm{TN}+\mathrm{FN}+\mathrm{TP}+\mathrm{FP})} \ldots \ldots \ldots \ldots \ldots \ldots \ldots(1) \\
\text { Akurasi }=\frac{(589+108)}{(589+45+108+54)}=0,875628
\end{gathered}
$$

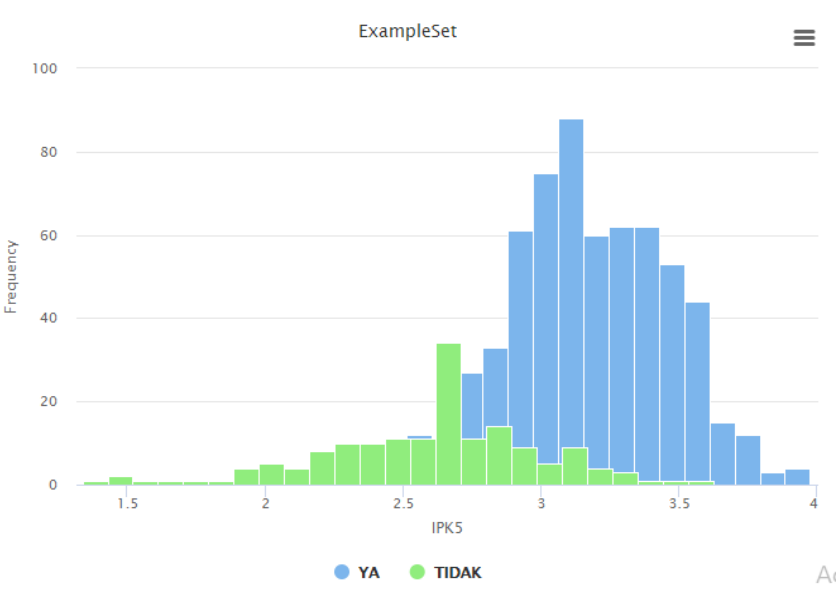

Gambar 5. Digram Batang Model Decision Tree Berbasis Particle Swarm Optimization 
Dengan rumus akurasi decision tree dengan particle swarm optimization tersebut dapat dihasilkan akurasi dengan model decisission tree berbasis particle swarm optimization sebesar 0.875628 atau diubah dengan persen senilai $87.56 \%$. Dari hasil prediksi kelulusan mahasiswa dapat dilihat dengan diagram batang pada Gambar 5 .

Dari diagram batang tersebut dapat juga dilihat kurva dengan model decision tree berbasis PSO, kurva tersebut merupakan area under curve (AUC) yang dapat dilihat dari gambar 6.

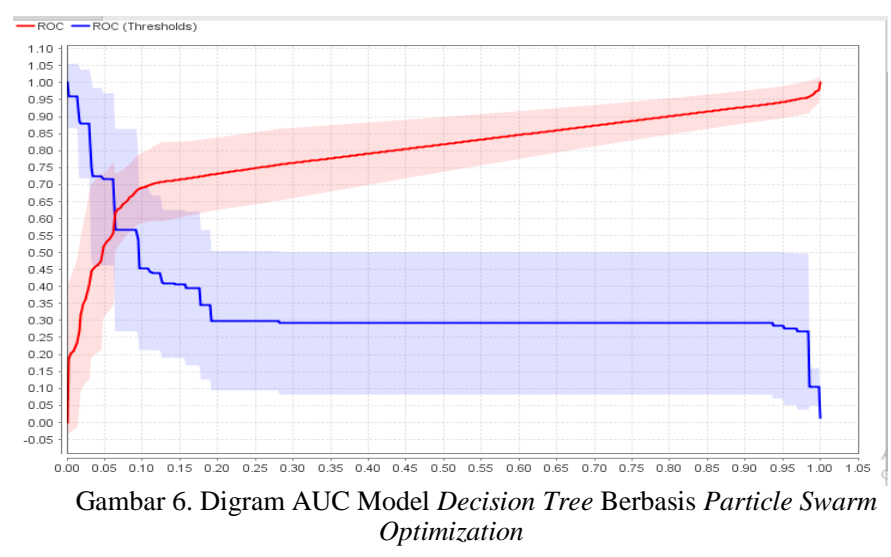

Dari hasil uji coba dengan model decision tree berbasis PSO maka didapatkan rule algoritma kelulusan mahasiswa seperti gambar berikut.

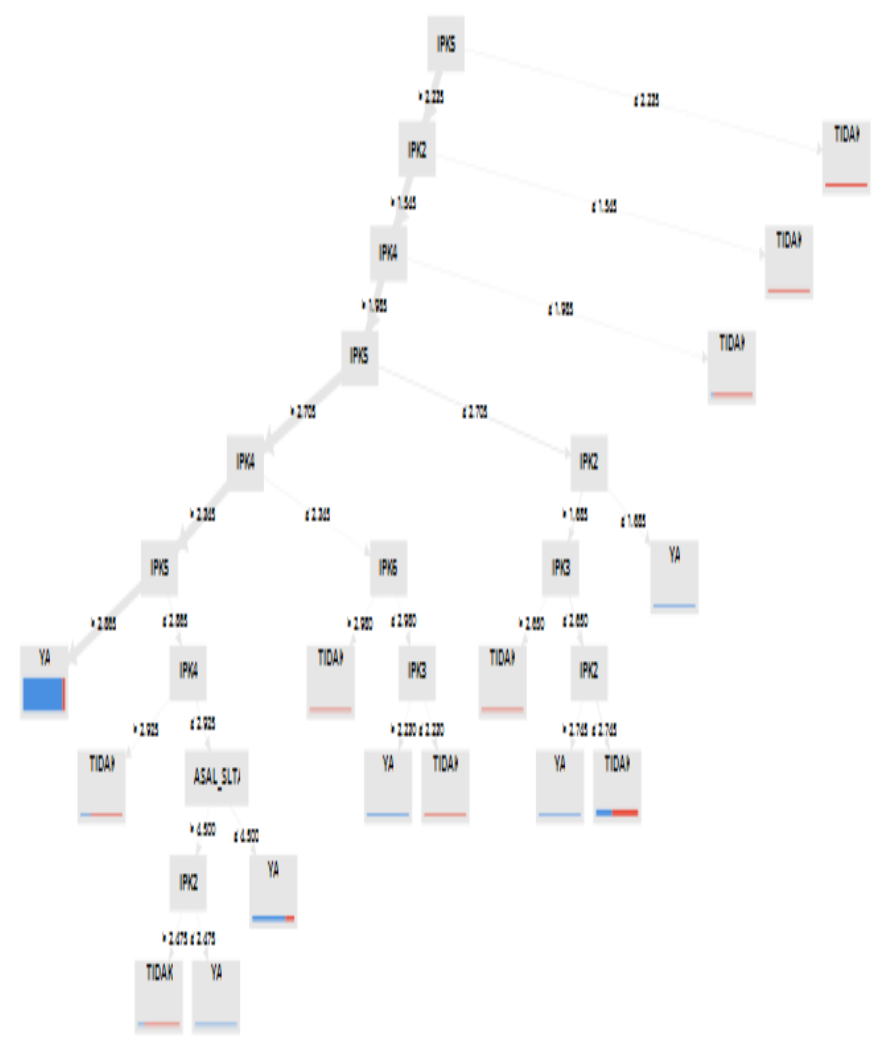

Gambar 7. Rule Algoritma Decision Tree Berbasis Particle Swarm Optimization

\section{KESIMPULAN}

Particle swarm optimization dengan meningkatkan kelemahan dari decision tree yang diusulkan dalam makalah ini yang mempunyai tujuan dalam menghilangkan parameter untuk mendapatkan satu set data kelulusan mahasiswa yang efektif. Dari data kelulusan mahasiswa yang di uji dengan menggunakan metode decision tree menunjukan bahwa particle swarm optimization berbasis decision tree yang berkinerja lebih baik dari pada metode decision tree yang tanpa optimasi.

Decision tree mendapatkan hasil akurasi sebesar $86.55 \%$ dengan prediksi kesalahan untuk mahasiswa yang lulus sebesar 107 data mahasiswa dimana data tersebut menyatakan bahwa yang seharusnya lulus tepat waktu dinyatakan tidak tepat waktu, dan sebaliknya yang tidak tepat waktu dinyatakan tepat waktu.

Particle swarm optimization mendapatkan hasil akurasi sebesar $87.56 \%$ dengan prediksi kesalahan untuk mahasiswa yang lulus sebesar 99 data mahasiswa dimana data tersebut menyatakan bahwa yang seharusnya lulus tepat waktu dinyatakan tidak tepat waktu, dan sebaliknya yang tidak tepat waktu dinyatakan tepat waktu.

Kenaikan akurasi dari metode particle swarm optimization sebesar $01.01 \%$ dan mengurangi kesalahan prediksi sejumlah 8 data mahasiswa. Dari hasil tersebut dapat digunakan oleh perguruan tinggi untuk menangulangi mahasiswa yang lulus tidak tepat waktu, sehingga akreditasi pada perguruan tinggi tersebut mendapatkan hasil yang baik.

\section{REFERENCES}

[1] V. Riyanto, A. Hamid, and Ridwansyah, "Prediction of Student Graduation Time Using the Best Algorithm," Indones. J. Artif. Intell. Data Min., vol. 2, no. 2, pp. 1-9, 2019.

[2] F. A. Freitas and L. J. Leonard, "Maslow's hierarchy of needs and student academic success," Teach. Learn. Nurs., vol. 6, no. 1, pp. 9-13, 2011.

[3] M. V. Ashok and A. Apoorva, "Data mining approach for predicting student and institution's placement percentage," 2016 Int. Conf. Comput. Syst. Inf. Technol. Sustain. Solut. CSITSS 2016, pp. 336-340, 2016.

[4] M. T. Devasia, M. V. T. P, and M. V. Hegde, "Prediction of Students Performance using Educational Data Mining," Int. J. Cogn. Ther., vol. 1, no. 3, pp. 266-279, 2008.

[5] Suhardjono, G. Wijaya, and A. Hamid, "PREDIKSI WAKTU KELULUSAN MAHASISWA MENGGUNAKAN SVM BERBASIS PSO,” Bianglala Inform., vol. 7, no. 2, pp. 97-101, 2019.

[6] Ridwansyah and E. Purwaningsih, "Particle Swarm Optimization Untuk Meningkatkan Akurasi Prediksi Pemasaran Bank," J. PILAR Nusa Mandiri, vol. 14, no. 1, pp. 83-88, 2018.

[7] H. M. Nawawi, S. Rahayu, J. J. Purnama, and S. I. Komputer, "Algoritma c4.5 untuk memprediksi pengambilan keputusan memilih deposito berjangka," J. Techno Nuasa Mandiri, vol. 16, no. 1, pp. 65$72,2019$.

[8] J. Han and M. Kamber, Data Mining Concept and Techniques. India: New Age International Limited, 2006.

[9] Wu and Kumar, The Top Ten Algorithms in Data Mining. USA: CRC Press, 2009.

[10] C. A. Sugianto, "Penerapan Teknik Data Mining Untuk Menentukan Hasil Seleksi Masuk Sman 1 Cibeber Untuk Siswa Baru Menggunakan Decision Tree," Tedc, vol. 9, pp. 39-43, 2015.

[11] F. Gorunescu, Data Mining: Concepts, Models and Technique. 2011.

[12] D. Setiawati, I. Taufik, J. Jumadi, and W. B. Zulfikar, "Klasifikasi Terjemahan Ayat Al-Quran Tentang Ilmu Sains Menggunakan Algoritma Decision Tree Berbasis Mobile," J. Online Inform., vol. 1, no. 1 , p. $24,2016$. 
[13] H. Liu, H. Q. Tian, C. Chen, and Y. F. Li, "An experimental investigation of two Wavelet-MLP hybrid frameworks for wind speed prediction using GA and PSO optimization," Int. J. Electr. Power Energy Syst., vol. 52, no. 1, pp. 161-173, 2013.

[14] T. Xu, Q. Peng, and Y. Cheng, "Identifying the semantic orientation of terms using S-HAL for sentiment analysis," Knowledge-Based Syst., vol. 35, pp. 279-289, 2012.

[15] J. Cao, H. Cui, H. Shi, and L. Jiao, "Big data: A parallel particle swarm optimization-back-propagation neural network algorithm based on MapReduce," PLoS One, vol. 11, no. 6, pp. 1-17, 2016.

[16] W. Dai and J. W, "A mapreduce implementation of C4.5 decision tree algorithm," in nternational Journal ofDatabase Theory and Application, 2014, pp. 49-60.

[17] L. Bin and Y. Min, "Analysis model of drilling tool failure based on PSO-SVM and its application," Proc. - 4th Int. Conf. Comput. Inf. Sci. ICCIS 2012, no. 8, pp. 1307-1310, 2012. 